\title{
Benefit of dual-energy CT iodine overlay technique for T1-hyperintense brain lesion
}

Figure $\quad$ MRI/CT images of residual glioblastoma
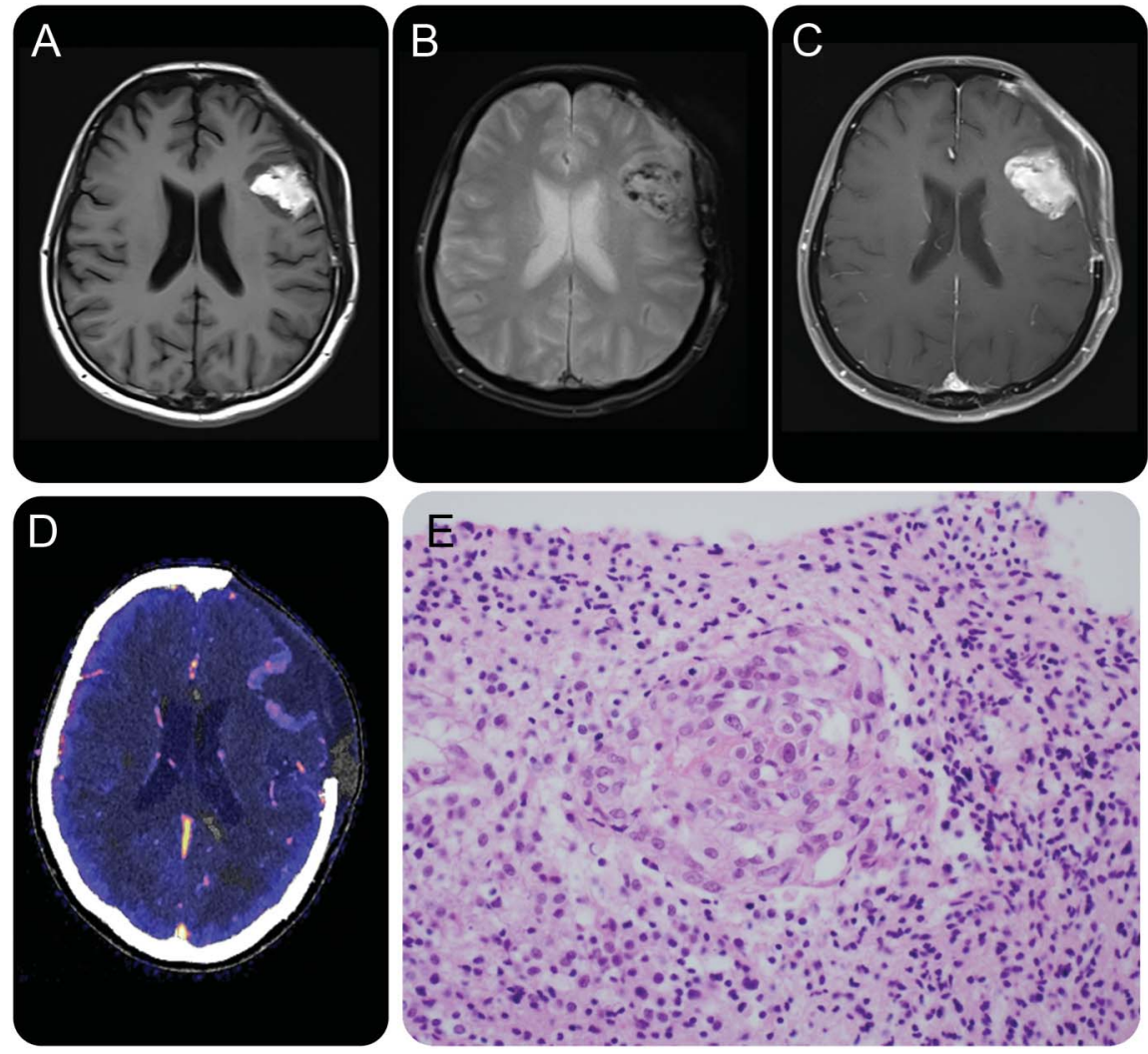

Because the signal intensity at the previous resection site is hyperintense on precontrast $\mathrm{T} 1$ image $(\mathrm{A})$ due to hemorrhage ( $\mathrm{B} ; \mathrm{T}^{*}$ gradient recalled echo), it is difficult to identify the tumoral enhancement ( $\mathrm{C}$; postcontrast T1). However, dual-energy CT iodine-overlay image (D) reveals the previously undetectable enhancement along the periphery. Biopsy was consistent with glioblastoma multiforme ( $E_{\text {; }}$ hematoxylin \& eosin, $\left.\times 200\right)$.

A 47-year-old woman was admitted for radiation therapy of a left frontal glioblastoma, resected 2 months prior. On enhanced MRI, it was difficult to identify the tumor enhancement due to intrinsic T1 hyperintensity, possibly related to postoperative hemorrhage ${ }^{1}$ (figure, A-C). However, the iodine overlay image derived from the dual-energy CT technique (figure, D) was revealing: subsequent surgical resection confirmed residual tumor cells along the region that showed the elevated iodine concentration (figure, E). The dual-energy CT iodine overlay technique may be particularly useful in the evaluation of a T1-hyperintense lesion. ${ }^{2}$

Younghen Lee, MD, PhD, Hyung Suk Seo, MD, PhD, Bo-Kyung Je, MD, PhD, Sang-Dae Kim, MD, PhD, Hwa Eun Oh, MD, PhD

From the Departments of Radiology (Y.L., H.S.S., B.-K.J.), Neurosurgery (S.-D.K.), and Pathology (H.E.O.), Ansan Hospital, Korea University College of Medicine, South Korea.

Author contributions: Y. Lee, H. Seo, B.-K. Je, S.-D. Kim, and H. Oh were involved in the neurologic patient care and analysis and interpretation of clinical results and data. Y. Lee drafted the manuscript. H. Seo, S.-D. Kim, B.-K. Je, and H. Oh revised the manuscript. Study funding: No targeted funding reported.

Disclosure: The authors report no disclosures relevant to the manuscript. Go to Neurology.org for full disclosures.

Correspondence to Dr. Lee: younghen@korea.ac.kr 
1. Ginat DT, Meyers SP. Intracranial lesions with high signal intensity on T1-weighted MR images: differential diagnosis. Radiographics 2012;32:499-516.

2. Yamauchi H, Buehler M, Goodsitt MM, Keshavarzi N, Srinivasan A. Dual-energy CT-based differentiation of benign posttreatment changes from primary or recurrent malignancy of the head and neck: comparison of spectral Hounsfield units at 40 and 70 $\mathrm{keV}$ and iodine concentration. AJR Am J Roentgenol 2016;206:580-587.

\section{WriteClick ${ }^{\circledR}$ rapid online correspondence}

The editors encourage comments about recent articles through WriteClick:

Go to Neurology.org and click on the "WriteClick" tab at the top of the page. Responses will be posted within 72 hours of submission.

Before using WriteClick, remember the following:

- WriteClick is restricted to comments about studies published in Neurology within the last eight weeks

- Read previously posted comments; redundant comments will not be posted

- Your submission must be 200 words or less and have a maximum of five references; reference one must be the article on which you are commenting

- You can include a maximum of five authors (including yourself)

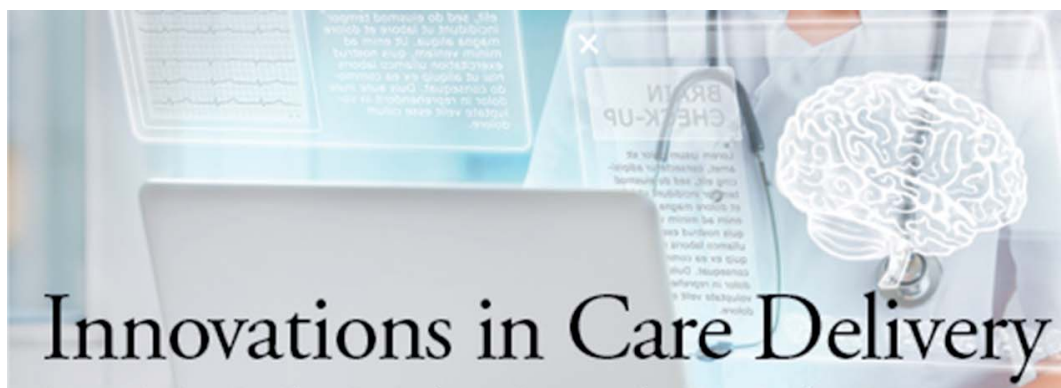

A curated collection featuring advances in neurologic care

NEW!

\section{Innovations in Care Delivery - A curated collection featuring advances in neurologic care}

This $N$ eurology ${ }^{\circledR}$ special interest website provides a forum to explore new care models from multiple disciplines, access to sources on health care innovation, and expert opinions on current research from Neurology journals. Curated by Brian C. Callaghan, MD, and Kevin A. Kerber, MD.

Stay ahead of the curve at Neurology.org/innovations. 


\section{Neurology}

\section{Benefit of dual-energy CT iodine overlay technique for T1-hyperintense brain lesion}

Younghen Lee, Hyung Suk Seo, Bo-Kyung Je, et al.

Neurology 2017;89;1426-1427

DOI 10.1212/WNL.0000000000004424

This information is current as of September 25, 2017

Updated Information \&

Services

References

Subspecialty Collections

Permissions \& Licensing

Reprints including high resolution figures, can be found at:

http://n.neurology.org/content/89/13/1426.full

This article cites 2 articles, 0 of which you can access for free at: http://n.neurology.org/content/89/13/1426.full\#ref-list-1

This article, along with others on similar topics, appears in the following collection(s):

Clinical neurology history

http://n.neurology.org/cgi/collection/clinical_neurology_history

CT

http://n.neurology.org/cgi/collection/ct

MRI

http://n.neurology.org/cgi/collection/mri

Primary brain tumor

http://n.neurology.org/cgi/collection/primary_brain_tumor

Surgical therapy-tumor

http://n.neurology.org/cgi/collection/surgical_therapytumor

Information about reproducing this article in parts (figures,tables) or in its entirety can be found online at:

http://www.neurology.org/about/about_the_journal\#permissions

Information about ordering reprints can be found online:

http://n.neurology.org/subscribers/advertise

Neurology ${ }^{\circledR}$ is the official journal of the American Academy of Neurology. Published continuously since 1951, it is now a weekly with 48 issues per year. Copyright (O 2017 American Academy of Neurology. All rights reserved. Print ISSN: 0028-3878. Online ISSN: 1526-632X.

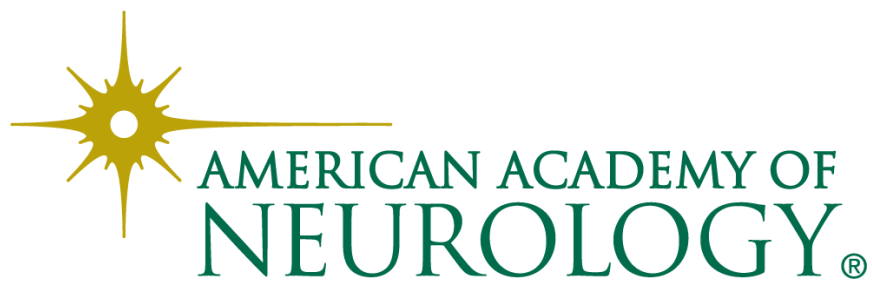

